\section{Pemeriksaan}

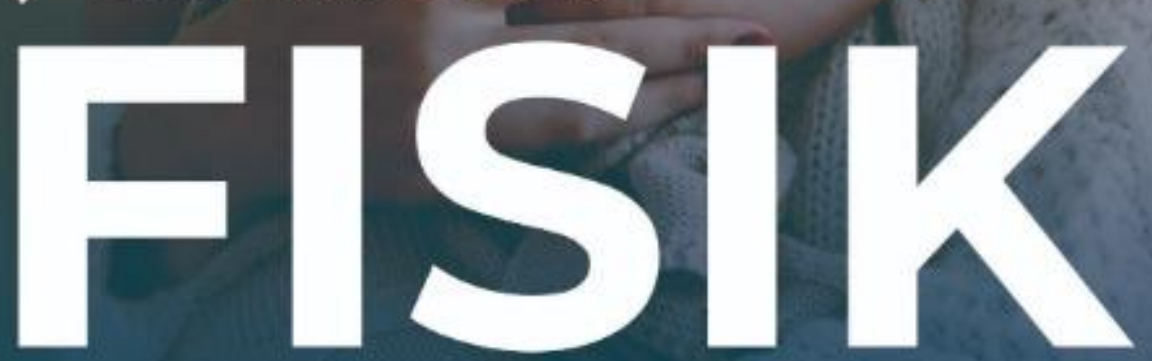

\section{IBU \& BAYI}

Pemeriksaan Fisik Ibu dan Bayi merupakan salah satu keterampilan dasar bagi tenaga kesehatan sebelum memberikan asuhan ataupun pelayanan kesehatan. Pengkajian dan pemeriksaan Fisik yang baik, akan memudahkan tenaga kesehatan dalam menegakkan diagnosa dan mengambil keputusan klinis.

Buku Pemeriksaan Fisik Ibu dan bayi merupakan karya bersama tim dosen Universitas Batam, yang terdiri dari 6 Bab yang berisi tentang Anamnesa, Pengkajian tanda fital Ibu dan Bayi, Pemeriksaan dasar pada Kehamilan, Persalinan dan Nifas Pemeriksaan Fisik bayi baru lahir dan balita, Evidance Based serta Standar Operational Prosedur.

Buku ini di sajikan dengan sederhana agar mudah dipahami. Kami berharap buku ini dapat menambah pengetahuan dan menjadi pedoman praktek bagi tenaga kesehatan khususnya mahasiswa bidang kesehatan dalam melakukan pemeriksaan fisik bagi Ibu dan Bayi

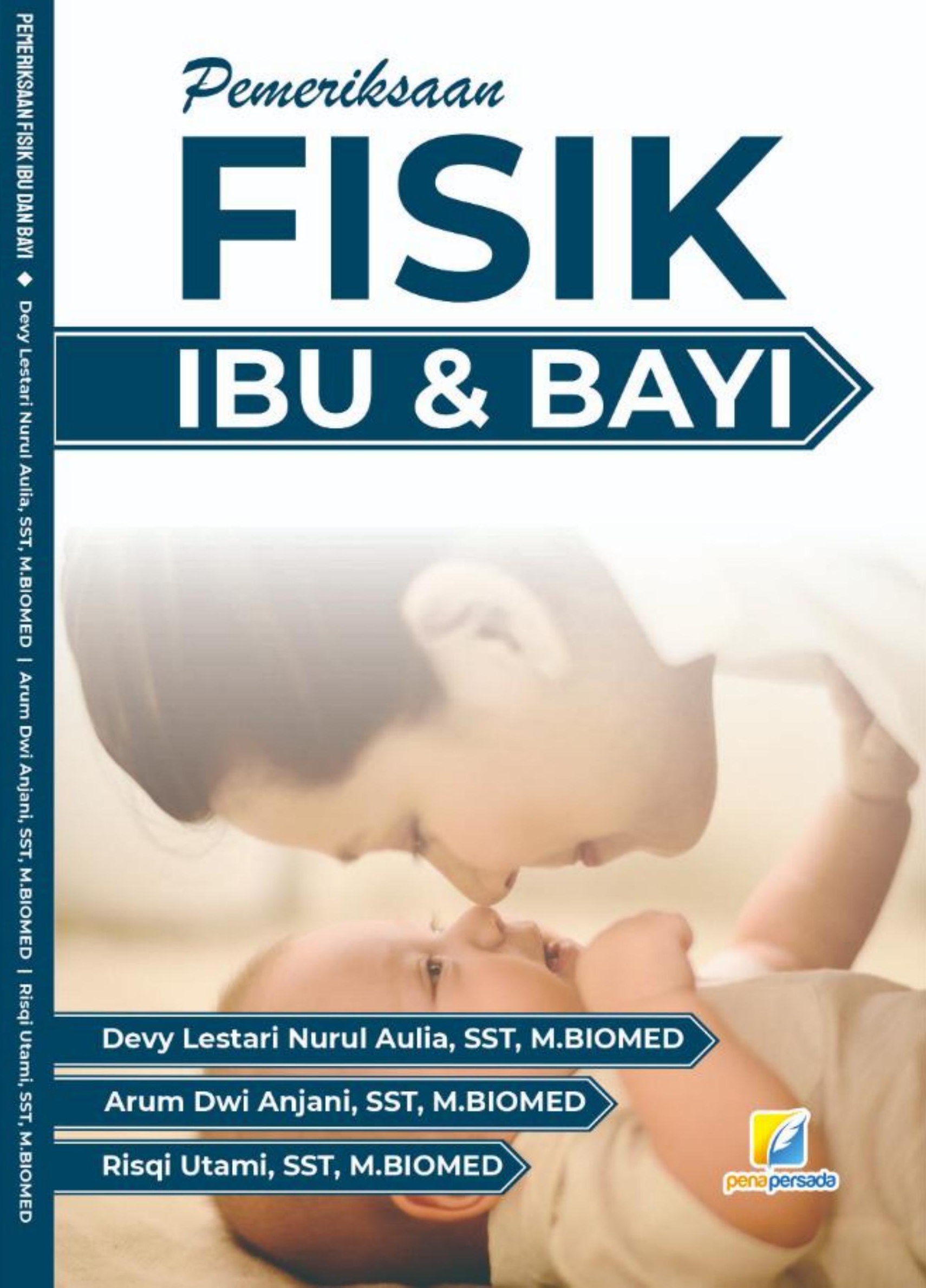




\title{
PEMERIKSAAN FISIK IBU DAN BAYI
}

\author{
DEVY LESTARI NURUL AULIA, SST, M.BIOMED \\ ARUM DWI ANJANI, SST, M.BIOMED \\ RISQI UTAMI, SST, M.BIOMED
}

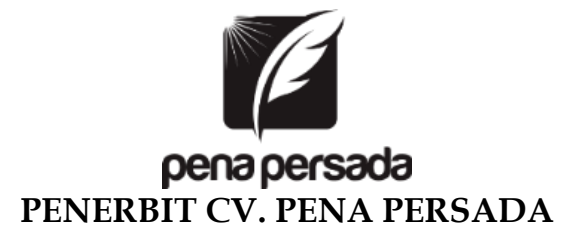




\title{
PEMERIKSAAN FISIK IBU DAN BAYI
}

\author{
Penulis: \\ Devy Lestari Nurul Aulia, SST, M.BIOMED \\ Arum Dwi Anjani, SST, M.BIOMED \\ Risqi Utami, SST, M.BIOMED
}

ISBN: 978-623-315-871-8

\section{Design Cover:}

Arsyie Kania Rakhma

\author{
Layout: \\ Nisa Falahia \\ Penerbit CV. Pena Persada \\ Redaksi:
}

Jl. Gerilya No. 292 Purwokerto Selatan, Kab. Banyumas

Jawa Tengah

Email: penerbit.penapersada@gmail.com

Website: penapersada.com Phone: (0281) 7771388

Anggota IKAPI

All right reserved

Cetakan pertama: 2021

Hak Cipta dilindungi oleh undang-undang. Dilarang memperbanyak karya tulis ini dalam bentuk apapun tanpa izin penerbit 


\section{KATA PENGANTAR}

Alhamdulillah, segala puji Kami panjatkan kepada Allah SWT atas ridho dan rahmad-Nya sehingga penulis mampu menyelesaikan buku berjudul Pemeriksaan Fisik Ibu dan Bayi dengan baik.

Penyusunan buku ini tentu tidak akan terwujud tanpa adanya dukungan dan bantuan dari berbagai pihak. Untuk itu penulis mengukapkan terimakasih yang tak terhingga kepada semua pihak yang terkait atas bantuan, motivasi, doa serta semangat yang tak pernah putus. Semoga Buku ini dapat bermanfaat bagi semua pihak.

Kami menyadari bahwa buku ini tidak luput dari kekurangan dan kesalahan. Oleh karena itu kami mengharapkan saran dan masukan yang membangun dari semua pihak demi penyempurnaan buku ini.

Wassalamu'alaikum

Penulis 


\section{DAFTAR ISI}

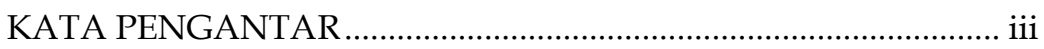

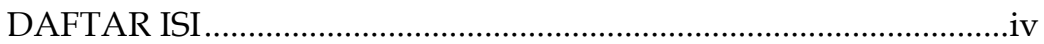

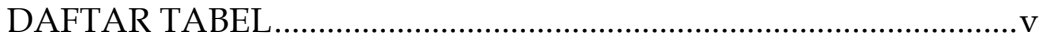

DAFTAR GAMBAR …..............................................................

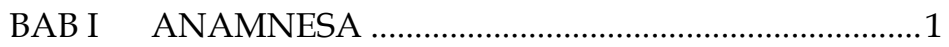

BAB II PENGKAJIAN TANDA VITAL IBU DAN BAYI .38

BAB III PEMERIKSAAN DASAR PADA KEHAMILAN, PERSALINAN DAN NIFAS ................................... 88

BAB IV PEMERIKSAAN BAYI BARU LAHIR, BAYI DAN ANAK …....................................................... 140

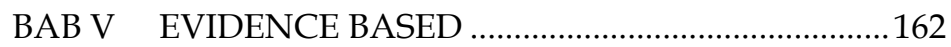

BAB VI STANDAR OPERATIONAL PROSEDURE.........168

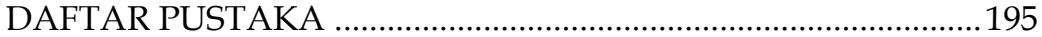

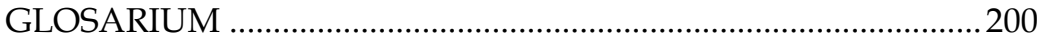

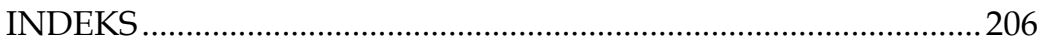

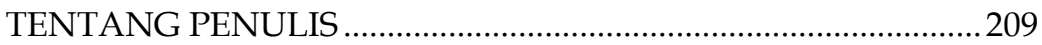




\section{DAFTAR TABEL}

Tabel 3.1 Prosedur praktikum ANC ................................................. 94

Tabel 3.2 Tinggi Fundus Uteri menurut Mc Donal ...................... 110

Tabel 3.3 Tinggi Fundus Menurut Leopold (Dalam cm) ............. 111

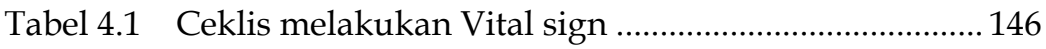

Tabel 4.2 Ceklis pengukuran Antopometri ................................... 150

Tabel 6.1 SOP Pengukuran Berat Badan ..........................................168

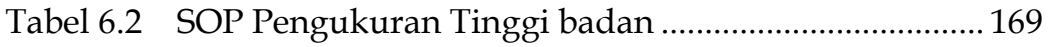

Tabel 6.3 SOP Pengukuran Suhu ................................................170

Tabel 6.4 SOP Pengukuran Tekanan Darah.................................. 172

Tabel 6.5 SOP Pemeriksaan Respirasi ........................................... 173

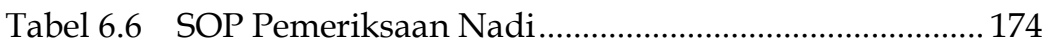

Tabel 6.7 SOP Anamnesis Ibu Hamil Kunjungan Awal .............. 175

Tabel 6.8 SOP Anamnesis Ibu Hamil Kunjungan Ulang ............. 177

Tabel 6.9 SOP Pemeriksaan Fisik Ibu Hamil ................................. 178

Tabel 6.10 SOP Pengukuran LILA .................................................. 181

Tabel 6.11 SOP Pemeriksaan Abdomen pada Ibu Hamil .............. 182

Tabel 16.2 SOP Pemeriksaan Kadar Hb ......................................... 184

Tabel 6.13 SOP Pemeriksaan Glukosa Urine .................................... 186

Tabel 6.14 SOP Pemeriksaan Protein Urine ..................................... 187

Tabel 6.15 SOP Pemeriksaan Ginetalia............................................ 189

Tabel 6.16 SOP Pemeriksaan Fisik Ibu Nifas ................................... 190

Tabel 6.17 SOP Pemeriksaan Fisik Bayi Baru Lahir........................ 193 


\section{DAFTAR GAMBAR}

Gambar 3.1 TFU Menurut Tuanya kehamilan....................................111

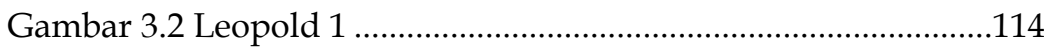

Gambar 3.3 Leopold II..................................................................115

Gambar 3.4 Leopold III ................................................................116

Gambar 3.5 Leopold IV ...................................................................117

Gambar 3.6 Posisi Rebozo Sifting ....................................................123

Gambar 3.7 Posisi Formard Leaning Inversion .................................124

Gambar 3.8 Posisi Sidelying Release .............................................124

Gambar 4.1 Pemeriksaan Tinggi / Panjang Badan ..........................154

Gambar 4.2 Pemeriksaan Lingkar Kepala .......................................156

Gambar 4.3 Bentuk Kepala ...........................................................158

Gambar 4.4 Pemeriksaan Hidung ……………................................159 


\section{BAB I \\ ANAMNESA}

\section{A. Pengertian}

Pengkajian adalah proses pengumpulan data secara sistematis yang bertujuan untuk menentukan status kesehatan dan fungsional klien pada saat ini dan waktu sebelumnya, serta untuk menentukan pola respon klien saat ini dan waktu sebelumnya (Potter, 2019)

Pengkajian adalah usaha yang dilakukan oleh tenaga kesehatan dalam menggali permasalahan dari klien meliputi usaha pengumpulan data tentang status kesehatan seorang klien secara sistematis, menyeluruh, akurat, singkat dan berkesinambungan (Muttagin, 2020)

Anamnesa adalah Cara pemeriksaan yang dilakukan dengan wawancara baik langsung pada pasien (Auto anamnese) atau pada orang tua atau sumber lain (Allo anamnese). $80 \%$ untuk menegakkan diagnosa didapatkan dari anamnese

Kegiatan dalam pengkajian adalah pengumpulan data. dalam pengumpulan data adalah kegiatan untuk menghimpun informasi tentang status kesehatan klien

Macam - macam Data

1. Data Data Dasar

Informasi mengenai status kesehatan pasien seperti : data umum, data demografi, dan riwayat kebidanan

2. Data Fokus

Ungkapan pasien maupun hasil pemeriksaaan langsung dari Bidan, jika pasien tidak sadar dapat diambil data hasil pemeriksaan

3. Data Subjektif

Ungkapan keluhan dari pasien secara langsung dan dapat diperoleh dari orang lain yang mengetahui keaadaan pasien secara langsung. contoh : merasa Mual, Pusing,nyeri pinggang, dan lain lain 


\section{Data Objektif}

Data yang diperoleh oleh bidan secara langsung melalui observasi dan pemeriksaan pada pasien. contoh : tekanan darah 120/80 mmHg,Odema pada kaki, konjungtiva anemis dll.

\section{Sumber Data}

\section{Sumber Data Primer}

sumbernya adalah klien itu sendiri. Jika klien tidak sadar atau masih bayi bidan dapat menggunakan data objektif untuk menegakan Diagnosis Kebidanan

\section{Sumber Data Sekunder}

sumbernya adalah keluarga, orang terdekat, dan orang lain yang tahu tentang status kesehatan klien. Selain itu tenaga kesehatan lain seperti dokter,ahli gizi, laboratorius, ahli gizi, dll

\section{Teknik Pengumpulan Data}

\section{Anamnesa}

Anamnesis adalah tanya jawab secara langsung dengan klien atau autoanamnesis maupun secara tidak langsung dengan keluarga atau alloanamnesis untuk menggali tentang status kesehatan klien. dalam anamnesis ini bidan membangun hubungan saling percaya antara pasien dengan bidan.

2. Obserfatif

tindakan yang mengamati secara umum terhadap perilaku dan keadaan pasien

3. Pemeriksaan

Pemeriksan fisik merupakan pemeriksaan tubuh untuk menemukan kelainan dari suatu sistim atau suatu organ tubuh dengan empat metode yaitu melihat (inspeksi), meraba (palpasi),mengetuk (perkusi) dan mendengarkan atau auskultasi (Raylene M Rospond, 2009; Lyrawati, 2009). Pemeriksaan fisik head to toe perlu dilakukan dengan benar karena hasil pemeriksaan fisik dapat dijadikan dasar bagi 
bidan untuk menegakkan diagnosa kebidanan yang selanjutnya sebagai dasar asuhan kebidanan

\section{B. Tujuan Pengkajian / Anamnesa}

1. Untuk mendapatkan keterangan sebanyak-banyaknya mengenai penyakit pasien

2. Membantu menegakkan diagnosa sementara. Ada beberapa penyakit yang sudah dapat ditegaskan dengan anamnese saja

3. Menetapkan diagnosa banding

4. Membantu menentukan penatalaksanaan selanjutnya

5. Mengevaluasi hasil asuhan Kebidanan.

\section{Pengkajian Riwayat Kesehatan dan Obstetri}

1. Pengkajian Identitas Pasien

a. Nama

Nama pasien dan suami, untuk mempermudah bidan dalam mengetahui pasien, sehinga dapat diberikan asuhan yang sesuai dengan kondisi pasien, selain itu juga dapat mempererat hubungan antara bidan dan pasien sehingga dapat meningkatkan rasa percaya pasien terhadap bidan

Nama pasien harus lengkap dan jelas sesuai tanda pengenal, untuk memastikan bahwa yang di periksa benar - benar pasien yang di maksud sehingga dapat memberikan asuhan yang sesuai dengan kondisi pasien. Kesalahan idetifikasi dapat berakibat fatal baik secara medis, etika maupun hukum.

b. Umur

Untuk mengetahui apakan pasien memiliki usia resiko tinggi atau tidak, sehingga jika pasien berisiko dapat diantisipasi sedini mungkin. Terkadang di gunakan untuk memperkirakan kemungkinan penyakit yang di alami, beberapa kondisi khas untuk umur tertentu.

c. Jenis Kelamin 
d. Pendidikan

untuk mengetahui jenjang pendidikan pasien maupun suami sehingga bidan dapat menggunakan kata-kata yang sesuai dengan jenjang pendidikan pasien/ suami.

Misalnya, penggunaan bahasa pada pasien yang pendidikan terakhirnya hanya Sekolah Dasar tentu saja berbeda dengan pasien yang pendidikan terakhirnya S1

e. Alamat

untuk mempermudah bidan dalam memberikan asuhan dan menghubungi pasien dan suami

f. Agama

untuk memotivasi pasien dengan kata-kata yang bersifat religius, terutama pada pasien dengan gangguan psikologis

g. Suku Bangsa

untuk mengetahui kebudayaan dan perilaku/ kebiasaan pasien, apakah sesuai atau tidak dengan pola hidup sehat. Berhubungan dengan kebiasaan tertentu atau penyakit yang berhubungan dengan ras/suku tertentu. Kepercayaan dan tradisi dapat menunjang atau menghambat hidup sehat.

h. Pekerjaan

untuk mengetahui keadaan ekonomi pasien, sehingga saat diberikan asuhan dapat disesuaikan dengan

kondisi ekonominya

i. No Telepon / HP

Untuk mempermudah bidan menghubungi pasien atau suami maupun keluarga terdekat saat terjadi kondisi gawat darurat

j. Keluhan Utama

Gangguan terpenting yang dirasakan klien sampai perlu pertolongan, dan menyebabkan penderita datang berobat kemudian ditanya keluhan tambahan. 
Setiap pasien yang datang ke bidan pasti mempunyai alasan. Menggali keluhan utama atau alasan datang bertujuan untuk mengetahui keluhan yang mendorong pasien untuk datang. Keluhan utama berbeda dengan alasan datang, alasan datang pasti akan berobat atau berkonsultasi, sedangkan keluhan utama lebih spesifik dari alasan datang contohnya mengenai penyakitnya atau masalah psikososial.

Keluhan utama adalah alasan utama yang menyebabkan pasien datang memeriksakan diri atau dibawa keluarganya ke dokter atau rumah sakit. Keluhan utama merupakan titik tolak penelusuran informasi mengenai penyakit yang dialami pasien saat ini Pengkajian Keluhan utama untuk mempermudah bidan dalam memberikan asuhan dan menegakkan diagnosa pada tahap selanjutnya, apakah keluhan pasien merupakan hal yang fisiologis atau patologis. Dalam mengkaji keluhan pasien agar efektif maka gunakan (PQRST)

P : Provokatif / Paliatif (Faktor Penyebab keluhan yang dirasakan)

Q : Qualitas / Quantitas (Kualitas dari masalah/ keluhan yang dirasakan klien)

R : Region/Radiasi (Area atau tempat terjadinya masalah/keluhan yang dirasakan klien)

S : Scale (Seberapa besar keluhan atau masalah yang dirasakan klien)

$\mathrm{T} \quad$ : Timing (Waktu keluhan/ masalah muncul atau berapa lama durasi)

Contoh: Ibu mengatakan terlambat haid sejak 2 bulan yang lalu mengeluh mual muntah $\geq$ 5 kali sehari terutama pada pagi hari, disertai pusing, nyeri ulu hati dan kurang nafsu makan, ibu merasa lemah dan sulit untuk beraktivitas.

$\mathrm{P} \quad$ : terlambat haid sejak 2 bulan yang lalu

$\mathrm{Q} \quad$ : mengeluh mual muntah $\geq 5$ kali sehari

$\mathrm{R}$ : disertai pusing, nyeri ulu hati dan kurang nafsu makan 
S : ibu merasa lemah dan sulit untuk beraktivitas.

$\mathrm{T} \quad$ : mual muntah terutama pada pagi hari

2. Riwayat kesehatan saat ini

Keluhan yang dirasakan pasien sejak gejala pertama sampai saat dilakukan, sejak kapan keluhan dirasakan, berapa lama dan berapa kali keluhan tersebut terjadi.

3. Riwayat Obstetri

a. Riwayat Menstruasi (Usia Menarche, siklus Menstruasi, Durasi, HPHT (Pada pasien Hamil dan Persalinan)

b. Riwayat kehamilan, Persalinan, Nifas Terdahulu Pengkajian pada riwayat kehamilan yang lalu bertujuan untuk melakukan asuhan kehamilan ( konseling, tindakan lanjut dan perencanaan persalinan) pengkajian pada riwayat kehamilan, persalinan dan nifas yang lalu meliputi :

1) Jumlah persalinan dengan G.. P.. A.. yaitu Gravida (Jumlah Kehamilan), Para (Jumlah Persalinan dan Abortus (Jumlah Keguguran), anak yang lahir hidup, persalinan aterm, persalinan premature, keguguran, persalinan dengan tindakan (Forcep, Vakum Ekstraksi dan Sectio Caesaria)

2) Riwayat perdarahan pada kehamilan, persalinan atau nifas sebelumnya

3) Hipertensi disebabkan kehamilan pada kehamilan sebelumnya

4) Berat bayi kurang dari 2500 gram atau lebih dari 4000 gram Masalah-masalah lain yang dialami

c. Riwayat Penggunaan Kontrasepsi (Jenis Kontrasepsi, Lama Pemakaian, keluhan)

d. Riwayat Kesehatan

1) Riwayat Kesehatan Ibu Untuk mengetahui karakteristik personal, riwayat penyakit menular/ keturunan dan riwayat pengobatan. 
2) Riwayat kesehatan keluarga Untuk mengetahui adaya resiko penyakit menular/keturunan dan kelainankelainan genetik

e. Data Psikososial

1) Riwayat perkawinan

a) Usia pada saat menikah

Tujuannya untuk mengetahui usia awal pasien saat menikah. Apakah secara fisik dan psikologis pasien sudah siap menikah, karena hal ini berkaitan dengan trauma psikologis ibu . Bagi pasien yang tidak siap menikah, baik dari segi fisik dan psikologis akan cenderung memiliki gangguan traumatis yang bersifat seumur hudup. Dan ini akan berpengaruh teruhadap perilaku ibu dalam kehamilan, persalinan maupun saat merawat bayi nya.

b) Lama menikah dan pernikahan ke

Tujuannya adalah untuk mengetahui berapa lama usia perkawinan pasien dan mengkaji bagaimana interaksi pasien dalam kehidupan rumah tangga. Contohnya ibu hamil yang sudah menikah 10 tahun, akan tetapi baru pertama kali hamil. Dalam kasus ini dapat di kaji bahwa kehamilan ini merupakan kehamilan yang sangat di tunggu.

c) Status perkawinan

Hal ini penting untuk di kaji karena dari data ini bidan akan mendapatkan gambaran mengenai suasana rumah tangga pasien. Apakah pasien menikah/tidak dan berhubungan dengan dukungan dari orang - orang sekitar pasien. Pada pasien hamil / bersalin / nifas yang tidak menikah, secara psikologis pasien tidak memiliki dukungan yang cukup dari orang - orang terdekatnya, sehingga rentan mengalamai trauma psikologis contohnya post partum blues. 
Apakah status pernikahan pasien sah / tidak, hal ini berhubungan dengan kondisi pasangan saat ini. Pasangan yang tidak mendapat respon baik dari sekitarnya akan cenderung menutup diri dan tidak mau berinteraksi. Kehidupan rumah tangga yang tertutup memicu terjadinya KDRT.

2) Respon suami dan keluarga terhadap kehamilan ini

3) Respons ibu terhadap kehamilan, persalinan atau kehadiran bayi

4) Hubungan ibu dengan anggota keluarga suami dan anggota keluarga yang lain

5) Adat setempat yang dianut dan berhubungan dengan kehamilan / persalinan / nifas

6) Pola Pemenuhan kebutuhan sehari - hari

a) Nutrisi, tanyakan pada klien jenis, kesukaan, pantangan, intake untuk mengetahui pemenuhan nutrisi, bidan dapat menggali informasi dari pasien tentang makanan yang di sukai dan yang tidak di sukai serta berapa banyak yang di konsumsi.

Yang perlu ditanyakan oleh bidan berkaitan dengan pola makan adalah :

Menu : Pola nutrisi seimbang, jika pengaturan menu makanan yang dilakukan pasien kurang seimbang sehingga da kemungkinan beberapa komponen gizi tidak terpenuhi, nidan dapat memberikan pendidikan kesehatan mengenai penyusunan menu seimbang bagi pasien

Frekuensi : Berapa kali asupan makanan yang di makan

Banyaknya: Seberapa banyak makanan yang pasien makan dalam satu kali waktu makan, untuk mendapatkan 
gambaran total dari makanan yang di makan, dikalikan dengan frekuensi malan dalam sehari.

Pantangan : Bidan perlu mencari tahu apakah ada kemungkinan pasien berpantang makanan yang justru sangan mendukung pemulihan fisiknya contoh : daging, ikan, telur

Pola Minum : Bidan mengumpulkan data pemenuhan kebutuhan dari pasien

Yang perlu di tanyakan adalah frekuensi (berapa kali pasien minum dalam sehari dan sekali minum habis berapa gelas), jenis minuman

b) Eliminasi, tanyakan pada klien perubahan yang terjadi baik BAB maupun BAK selama hamil.

c) Aktivitas dan Latihan, tanyakan ada gangguan atau tidak

d) Istirahat - Tidur. tanyakan tentang pola. lama, dan gangguan tidur baik pada waktu siang maupun malam.

e) Personal Hygien : Bidan perlu bertanya perawatan kebersiahan diri contohnya mandi, keramas, ganti baju dan celana dalam, kebersihan kuku

f) Seksualitas, tanyakan tentang pendidikan seksual dan kesiapan fungsi seksual, konsep seksual diri dan identitas, sikap terhadap seksualitas, efek terhadap kehamilan/persalinan/nifas

g) Persepsi dan Kognitif, kaji tentang status mental, pendengaran, berbicara, penciuman, perabaan, kejang, dan nyeri

h) Persepsi diri dan konsep diri, tanyakan motivasi terhadap kehamilan, efek kehamilan terhadap body image, orang terdekat, dan tujuan dari kehamilan.

i) Keyakinan budaya (culture). 
7) Kepercayaan dan Ibadah.

8) Kebiasaan yang merugi kan, seperti merokok, minum alkohol, dll

\section{Keterampilan komunikasi dalam anamnesa}

Komunikasi adalah menyampaikan pesan dari seseorang ke orang lain. Komunikasi merupakan seni penyampaian informasi (pesan, ide, sikap/gagasan) dari komunikator untuk mengubah/membentuk perilaku komunikan (pola, sikap, pandangan, dan pemahaman) ke pola pemahaman yang dikehendaki bersama. Sedangkan komunikasi kebidanan adalah bentuk komunikasi yang digunakan oleh bidandalam memberikan asuhan kebidanan kepada klien seperti misalnya ketika seorang bidan mencari data atau mengkaji klien, melaksanakan asuhan, ataupun melakukan evaluasi terhadap asuhan yang sudah diberikan.

\section{Komunikasi interpersonal}

Komunikasi intrapersonal adalah penyampaian pesan seseorang kepada dirinya sendiri. Komunikasi interpersonal : Penyampaian pesan dari seseorang kepada orang lain, bersifat dua arah, secara verbal maupun non verbal. Misalnya : komunikasi antara bidan dengan klien.

Komunikasi intrapersonal yang baik memberikan dasar bagi komunikasi interpersonal yang baik. Salah satu output dari komunikasi intrapersonal adalah kepercayaan diri dan keberanian untuk berkomunikasi. Bersamaan dengan itu, diperlukan kemampuan mendengar yang baik, sehingga tercipta komunikasi dua arah yang baik pula. Untuk meningkatkan kepercayaan diri, ada beberapa cara yang dapat dilakukan yaitu :

1. Mengatur fisiologi tubuh seperti mengatur nafas, mengatur gerakan kaki atau tangan yang tidak perlu dan tidak disadari

2. Melakukan proses kognitif di dalam pikiran seperti : defusi (Bicaralah dalam hati : "thank you mind,thank you for 
sharing"), kepasrahan - sikap nothing to loose (Bicaralah dalam hati : "Ya Tuhan aku memang gugup tapi aku pasrahkan kepada-Mu")

3. Menceritakan kelebihan diri dan mengakses keberhasilan masa lalu sehingga timbul self esteem (kebanggaan diri). Ingatlah.... bahwa bangga berbeda dengan sombong

4. Hindari bersikap perfeksionis karena SEMPURNA itu JEBAKAN. Tidak ada kegagalan dalam berbicara, yang ada hanyalah feedback

Klien sangat merasa dihargai oleh bidan yang mendengar mereka dengan positif dan penuh empati. Mendengar adalah keterampilan komunikasi yang paling banyak dibanding dengan keterampilan komunikasi yang lain. Penelitian Barker (1980) menunjukkan bahwa:

1. $53 \%$ komponen komunikasi adalah mendengar

2. $17 \%$ membaca

3. $16 \%$ berbicara

4. $14 \%$ menulis

Oleh karena itu keterampilan mendengar adalah keterampilan dasar yang sangat bermanfaat (valuable skill) yang harus dipelajari.

Empat bentuk Mendengarkan :

1. Mendengarkan pasif (diam)

2. Memberi tanda perhatian verbal seperti : oh gitu, ya, terus

3. Membuka pintu, undangan untuk berbicara yaitu mengajukan pertanyaan untuk mendalami dan klarifikasi

4. Mendengar aktif/Active listening (respon empati) : memberikan umpan balik/merefleksikan isi ucapan dan perasaan yaitu : merangkum, merefleksikan isi ucapan (paraphrasing) dan terutama refleksi perasaan. Disertai dengan tanggapan non verbal yang sesuai

Hal-hal yang harus dihindari dalam proses active listening:

1. Menasehati

2. Pengungkapan diri untuk menunjukkan simpati 
3. Tidak peduli

4. Memerintah

5. Menakut-nakuti

6. Berkhotbah

7. Mengadili

8. Mengejek

9. Menganalisa

10. Menunjukkan simpati

11. Mengalihkan perhatian

Tanggapan yang LEBIH TEPAT adalah dengan cara:

1. Merefleksi isi, merangkum

2. merefleksikan perasaan

Refleksi isi adalah merefleksi isi percakapan pasien dengan mengungkapkan kembali dengan kata-kata lain apa yang dianggap sebagai inti (Parafrasing) dari apa yang baru dikatakan pasien. Merefleksi isi adalah menggunakan sebagian dari kata-kata bidan yang ditambah dengan kata-kata pasien. Cara melakukan refleksi isi (Parafrasing) adalah dengan menggunakan kata-kata seperti :

"Jadi dengan kata lain......"

"Dari yang saya tangkap maksud ibu...."

"Jadi yang terjadi adalah......"

"Maksud ibu, bahwa......"

Refleksi perasaan berhubungan dengan emosi dari pasien. Perasaan utama pasien telah terpantau oleh bidan. Bidan mengamati verbal dan non verbal pasien kemudian mengatakan perasaan tersebut misalnya,"ibu sepertinya bingung.....", “ya saya mengerti ibu khawatir...." Refleksi perasaan harus dilakukan dengan respon non verbal yang sesuai. Ada beberapa respon non verbal yaitu :

1. Proksemik : Jarak (contoh : bidan mendekat)

2. Kinesik (Fasial/wajah dan Gestur/Gerakan sebagian anggota badan (contoh : bidan condong ke depan dan mimik wajah serius/prihatin) 
3. Paralingustik : tinggi rendah, tempo, nada, ritme suara (contoh : bidan memelankan suara saat pasien sedih)

\section{Empati}

Mendengar aktif adalah sebuah bentuk dari sikap empati. Komunikasi antara bidan dan klien dapat berjalan efektif jika bidan dapat memberikan sikap/respon empati kepada klien yang dihadapi.

Empati adalah kemampuan bidan untuk menempatkan diri pada situasi atau kondisi yang dialami klien sehingga bidan tanpa harus larut dalam suasana hati klien. Empati merupakan tingkatan tertinggi dari proses rapport (jalinan hubungan) antara seorang bidan dengan kliennya. Respon empati dapat dilakukan melalui mendengar empati dan berbicara

empati kepada klien. Mirip dengan mendengar, empati juga memiliki beberapa tahapan yang akan dijelaskan dalam kuliah. Byloun and Makoul (2002) dimana terdapat 6 level empati yaitu:

1. Level 0 : Bidan menolak sudut pandang pasien

2. Level 1 : Bidan mengenali sudut pandang pasien secara sambil lalu

3. Level 2 : Bidan mengenali sudut pandang pasien secara implisit

4. Level 3 : Bidan menghargai pendapat pasien

5. Level 4 : Bidan mengkonfirmasi kepada pasien

6. Level 5 : Bidan berbagi perasaan dan pengalaman

Fieldman dan Christensen (2008) memberikan 5 keterampilan empatikyang mudah dipahami dan dipraktekkan:

1. Reflection: "Ibu tampak sedih"

2. Validation : "Saya mengerti bapak marah dengan kondisi ini"

3. Support :"Bapak telah melakukan hal yang baik dalam mengatasi kesedihan bapak" 